contacts with the register who were not also admitted, for alcohol related diagnoses in 1981 .

In the Highlands and Kent all letters of reply to referring agents were read by RWL if a patient was a new referral in 1981. Those who were not admitted were counted as outpatient cases if alcohol was mentioned as a major contributory factor in their psychiatric presentation. In Kent numbers of first attenders at a day unit were easily and reliably obtained (to the exclusion of those admitted) from records held on computer. All patients admitted or seen as day patients for alcohol related diagnoses routinely complete the severity of alcohol dependence questionnaire. ${ }^{10}$ There were no day patients in the Highlands.

\section{RESULTS}

The figure shows the results. When psychiatric inpatient, outpatient, and day patient rates were added the total rates of morbidity due to alcohol treated by psychiatric services approximated. The ratio between rates in the Highlands and Kent was only $1.53: 1$, compared with 12.5:1 for psychiatric inpatient rates. A comparison of day patients and inpatients in Kent who completed the alcohol dependence questionnaire showed no significant differences.

\section{Conclusions}

These findings do not support the conventional view that there is a large north to south gradient in rates of treated morbidity due to alcohol. Patterns of alcohol consumption in the general population are reported in our accompanying paper. ${ }^{11}$

This study was funded by the Medical Research Council and by the Economic and Social Research Council. Additional support was provided by the Scotch Whisky Association and by the Brewers' Society. Some of the data will be included in a Birmingham University MD thesis.

\section{References}

1 Plant MA, Pirie F. Self-reported alcohol consumption and alcohol-related problems: a study in four Scottish towns. Soc Psychiatry 1979;14:65-73.

2 Kilich S, Plant MA. Regional variations in levels of alcohol-related problems in Britain. Br f Addict 1981;76:47-62. (Erratum 1982;77:211.)

3 Davies PT. The pattern of problems. In: Plant MA, ed. Drinking and problem drinking. London: Junction, 1982:111-34.

4 Haskey JC, Balarajan R, Donnan SPB. Regional variations in alcohol-related problems within the United Kingdom. Community Med $1983 ; 5: 208-19$.
Office of Population Censuses and Surveys Geral household survey Pfice of Population Censuses and Surveys. General household survey 1978. London: HMSO, 1980

6 Cummins RO, Shaper AG, Walker M, Wale CJ. Smoking and drinking by middle-aged British men: effects of social class and town of residence. Br Med 7 middle-283:1497-502.

7 Wilson SP. Drinking habits in the United Kingdom. Population Trends 1980; No 22, winter: 14-8.

8 Chick J. Alcohol dependence: methodological issues in its measurement: reliability of the criteria. $B r \mathcal{F}$ Addict $1980 ; 79: 175-86$

9 Edwards G, Gross M. Alcohol dependence: provisional description of a clinical syndrome. $\mathrm{Br}$ Med $\mathcal{F} 1976 ; \mathrm{i}: 1058-6$

10 Stockwell T, Hodgson R, Edwards G, Taylor C, Rankin H. The development of a questionnaire to measure severity of alcohol dependence. $\mathrm{Br} \mathcal{J}$ Addict $1979 ; 73: 79-87$

11 Crawford A, Plant MA, Kreitman N, Latcham RW. Regional variations in British alcohol morbidity rates: a myth uncovered? II : Population surveys.
$B r$ Med $\mathcal{f} 1984 ; 289: 1343-5$.

(Accepted 31 August 1984)

\title{
Regional variations in British alcohol morbidity rates: a myth uncovered? II: population surveys
}

\author{
ALEX CRAWFORD, MARTIN A PLANT, NORMAN KREITMAN， RICHARD W LATCHAM
}

\begin{abstract}
Regional variations in officially recorded rates of alcohol related morbidity in Britain were investigated by surveying community drinking habits of a randomly selected sample of adults in the Highlands, Tayside, and part of the South East Thames region. Contrary to expectations, patterns of alcohol consumption did not differ in a manner consistent with the much higher rates of alcohol related problems recorded in the north.
\end{abstract}

\section{Introduction}

In our accompanying paper we reported that officially recorded levels of alcohol related problems are much higher in the north of Britain than they are in the south. ${ }^{1}$ Paradoxically, evidence

\footnotetext{
University Department of Psychiatry, Royal Edinburgh Hospital, Edinburgh EH10 5HF

ALEX CRAWFORD, BA, MSC, research fellow, alcohol research group

MARTIN A PLANT, BSC, PHD, senior research fellow, alcohol research group

NORMAN KREITMAN, FRCP, FRCPSYCH, director, MRC unit for epidemiological studies in psychiatry

RICHARD W LATCHAM, MB, MRCPSYCH, research psychiatrist, MRC unit for epidemiological studies in psychiatry

Correspondence to: Mr A Crawford.
}

about the corresponding levels of alcohol consumption in different regions is both restricted and inconsistent. In order to clarify the position two surveys were conducted. Both of these related to the Highlands, Tayside, and south east Kent. The first survey is described in our accompanying paper and was concerned with clinically diagnosed problem drinkers. This paper reports the results of the second survey, which was concerned with patterns of alcohol consumption in the general population.

\section{Method}

Data were obtained by interviewing samples of people drawn from the electoral register in each of the three areas. The initial sampling pool comprised 40 electors from 40 polling districts in each area. The polling districts were randomly selected within each area by (a) ranking parliamentary wards by size of population (largest to smallest); (b) similarly ranking polling districts (or civil parishes in rural areas) within wards; (c) dividing the cumulative total of electors $(\mathrm{N})$ by 40 ; and $(d)$ randomly selecting a number (which corresponded to an elector) between one and N/40. The polling district within which that elector resided became the starting point for selecting the remaining 39 districts. This was achieved by adding (N/40) 39 times to that initial random number.

Forty respondents aged 18 and over on 1 September 1982 were randomly selected from each polling district by choosing every 10th elector after a randomly chosen starting number between one and $M-450 . M$ was the number of electors in the polling district. This procedure randomly produced 1600 names equally divided by sex in each of the three survey areas. In order to increase the chance 
of interviewing heavy drinkers the sample was weighted roughly $2: 1$ in favour of men. ${ }^{2}{ }^{3}$ To this end every second woman was removed from the sampling pool. An additional group of so called non-electors (people aged 18 and over and eligible to vote but not on the register) were added by the Kish grid method." The selection procedure automatically excluded people permanently living in institutions or who had no fixed abode. Electors were excluded from the sample without replacement if found to be dead, incarcerated in an institution, to have moved, or if their house was empty or demolished. Fieldwork was conducted between 8 September and 10 October 1982.

\section{Results}

A total of 2349 people were interviewed, representing a net response rate of $69 \%$ (table I). The response rate in Kent was slightly lower than in the two other areas $\left(x^{2}=6.06 ; \mathrm{df}=2 ; \mathrm{p}<0.05\right)$.

Reduced response rates in south east Britain have been noted in other studies. ${ }^{8-12}$

The numbers of respondents included in the following analyse varied from item to item owing to variations of responses to individual questions.

TABLE I-Response rates in three areas

\begin{tabular}{|c|c|c|c|c|c|c|c|c|}
\hline & \multicolumn{6}{|c|}{ Area } & & \\
\hline & \multicolumn{2}{|c|}{ Highland } & \multicolumn{2}{|c|}{ Tayside } & \multicolumn{2}{|c|}{ Kent } & \multicolumn{2}{|c|}{ All } \\
\hline & No & $\%$ & No & $\%$ & No & $\%$ & No & $\%$ \\
\hline $\begin{array}{l}\text { Electors (E) } \\
\text { Non-electors (NE) } \\
\text { Ineligibles (I) }\end{array}$ & $\begin{array}{r}1196 \\
85 \\
148\end{array}$ & & $\begin{array}{r}1199 \\
117 \\
164\end{array}$ & & $\begin{array}{r}1182 \\
81 \\
144\end{array}$ & & $\begin{array}{r}3577 \\
283 \\
456\end{array}$ & \\
\hline Total eligible $(\mathrm{E}+(\mathrm{NE}-\mathrm{I}))$ & 1133 & $100 \cdot 0$ & 1152 & $100 \cdot 0$ & 1119 & $100 \cdot 0$ & 3404 & $100 \cdot 0$ \\
\hline $\begin{array}{l}\text { Non-interviews } \\
\text { Non-contacts* } \\
\text { Refusals } \\
\text { Not possibles } \dagger \\
\text { Other reasons } \\
\text { Interviews } \\
\text { Complete } \\
\text { Prematurely terminated }\end{array}$ & $\begin{array}{r}335 \\
203 \\
89 \\
25 \\
18 \\
798 \\
794 \\
4\end{array}$ & $\begin{aligned} 29 \cdot 6 \\
17 \cdot 9 \\
7 \cdot 9 \\
2 \cdot 2 \\
1 \cdot 6 \\
70 \cdot 4 \\
70 \cdot 1 \\
0 \cdot 4\end{aligned}$ & $\begin{array}{r}342 \\
178 \\
137 \\
9 \\
18 \\
810 \\
805 \\
5\end{array}$ & $\begin{array}{r}29.7 \\
15.5 \\
11.9 \\
0.8 \\
1.6 \\
70.3 \\
69.9 \\
0.4\end{array}$ & $\begin{array}{r}378 \\
171 \\
124 \\
48 \\
35 \\
741 \\
731 \\
10\end{array}$ & $\begin{array}{r}33 \cdot 8 \\
15 \cdot 3 \\
11 \cdot 1 \\
4 \cdot 3 \\
3 \cdot 1 \\
66 \cdot 2 \\
65 \cdot 3 \\
0.9\end{array}$ & $\begin{array}{r}1055 \\
552 \\
350 \\
82 \\
71 \\
2349 \\
2330 \\
19\end{array}$ & $\begin{array}{r}31 \cdot 0 \\
16 \cdot 2 \\
10 \cdot 3 \\
2 \cdot 4 \\
2 \cdot 1 \\
69 \cdot 0 \\
68.4 \\
0.6\end{array}$ \\
\hline
\end{tabular}

Never in, not available.

†Senile, too ill or incapacitated, no English spoken.

TABLE II-Demographic details of respondents in three areas (percentages in parentheses)

\begin{tabular}{|c|c|c|c|c|c|}
\hline Variable & Respondent's sex & \multicolumn{3}{|c|}{ Area } & Level of significance \\
\hline Mean age of respondent (years) & $\stackrel{\mathbf{M}}{\mathrm{F}}$ & $\begin{array}{l}42 \cdot 7 \\
41 \cdot 6\end{array}$ & $\begin{array}{l}42 \cdot 6 \\
42 \cdot 2\end{array}$ & $\begin{array}{l}45 \cdot 3 \\
47 \cdot 5\end{array}$ & $\begin{array}{l}\text { Area: } F=4 \cdot 7 ; \mathrm{df}=2,2336 ; p<0 \cdot 001^{*} \\
\text { Sex: } \mathrm{F}=0.2 ; \mathrm{df}=1,2336 ; \mathrm{NS}^{*}\end{array}$ \\
\hline $\begin{array}{l}\text { Social class of head of household : } \\
\text { Non-manual } \\
\text { Manual }\end{array}$ & $\mathbf{M}$ & $\begin{array}{l}137(40 \cdot 4) \\
202(59 \cdot 6)\end{array}$ & $\begin{array}{l}152(42 \cdot 8) \\
203(57 \cdot 2)\end{array}$ & $\begin{array}{l}118(39 \cdot 1) \\
184(60 \cdot 9)\end{array}$ & $x^{2}=0.6 ; \mathrm{df}=2 ; \mathrm{NS} \dagger$ \\
\hline $\begin{array}{l}\text { Non-manual } \\
\text { Manual }\end{array}$ & $\mathbf{F}$ & $\begin{array}{l}78(61 \cdot 9) \\
48(38 \cdot 1)\end{array}$ & $\begin{array}{l}89(62 \cdot 7) \\
53(37 \cdot 3)\end{array}$ & $\begin{array}{l}80(65 \cdot 0) \\
43(35 \cdot 0)\end{array}$ & $\chi^{2}=0.3 ; \mathrm{df}=2 ; \mathrm{NS} \dagger$ \\
\hline
\end{tabular}

NS $=$ Not significant

*3 (Area) $\times 2$ (respondent's sex) analysis of variance.

+3 (Area) $\times 2$ (social class: manual $v$ non-manual) $\chi^{2}$ analysis for each sex.
tRegistrar General's scale.

TABLE III-Types of drinker in each of three areas

\begin{tabular}{|c|c|c|c|c|c|c|c|c|}
\hline \multirow{3}{*}{ Type of drinker } & \multirow{3}{*}{ Respondent's sex } & \multicolumn{6}{|c|}{ Area } & \multirow{3}{*}{ Level of significance* } \\
\hline & & \multicolumn{2}{|c|}{ Highland } & \multicolumn{2}{|c|}{ Tayside } & \multicolumn{2}{|c|}{ Kent } & \\
\hline & & No & $\%$ & No & $\%$ & No & $\%$ & \\
\hline Abstainer & $\stackrel{\mathbf{M}}{\mathbf{F}}$ & $\begin{array}{l}27 \\
46\end{array}$ & $\begin{array}{r}5.6 \\
14.6\end{array}$ & $\begin{array}{l}10 \\
23\end{array}$ & $\begin{array}{l}2 \cdot 0 \\
7 \cdot 2\end{array}$ & $\begin{array}{l}11 \\
26\end{array}$ & $\begin{array}{l}2.5 \\
8.7\end{array}$ & $\begin{array}{l}\text { Men: } \chi^{2}=17.6 ; p=0.002 \\
\text { Women: } \chi^{2}=16.5 ; p=0.003\end{array}$ \\
\hline Had not drunk alcohol in past 7 days & $\underset{\mathbf{F}}{\mathbf{M}}$ & $\begin{array}{l}145 \\
147\end{array}$ & $\begin{array}{l}30 \cdot 1 \\
46 \cdot 7\end{array}$ & $\begin{array}{l}117 \\
136\end{array}$ & $\begin{array}{l}23.9 \\
42.8\end{array}$ & $\begin{array}{l}114 \\
122\end{array}$ & $\begin{array}{l}26 \cdot 1 \\
40 \cdot 9\end{array}$ & \\
\hline Had drunk alcohol in past 7 days & $\stackrel{\mathbf{M}}{\mathbf{F}}$ & $\begin{array}{l}309 \\
122\end{array}$ & $\begin{array}{l}64 \cdot 2 \\
38 \cdot 7\end{array}$ & $\begin{array}{l}362 \\
159\end{array}$ & $\begin{array}{l}74 \cdot 0 \\
50 \cdot 0\end{array}$ & $\begin{array}{l}311 \\
150\end{array}$ & $\begin{array}{l}71 \cdot 3 \\
50 \cdot 3\end{array}$ & \\
\hline
\end{tabular}

3 (Region) $\times 3$ (drinker) $\chi^{2}$ test with 4 df conducted for each sex.

Respondents were interviewed privately by trained interviewers. A standardised interview schedule was employed. This took about 30. minutes to administer and elicited information about alcohol consumption, experience of alcohol related consequences, and attitudes to alcohol use and misuse together with biographical details. Many of these items were identical with those employed in relation to the clinical samples, so that data from both studies could be compared. Almost all items had been used in earlier studies ${ }^{5-7}$ (Kreitman et al, personal communication, 1984). Pretesting of the initial schedule was conducted by members of the alcohol research group on six colleagues in the psychiatry department of Edinburgh University. Piloting was carried out with 75 randomly selected members of the general public (five in Glasgow, 10 in Edinburgh, and 20 from each of the three study areas).
Biographical details-Respondents in Kent were significantly older than those in the Highlands $(t=2.56 ; \mathrm{df}=1.537 ; \mathrm{p}<0.01)$ and in Tayside $(t=3.8 ; \mathrm{df}=1.549 ; \mathrm{p}<0.001)$ (table II). The three areas did not differ in relation to respondents' social class (Registrar General's scale).

Self reported alcohol consumption-Details were obtained about alcohol consumption during the week preceding interview. This is a standard procedure employed in recent British studies of alcohol consumption. ${ }^{8-11}$

Types of drinker-Respondents were classified as abstainers, drinkers within the past seven days, and drinkers who had not consumed alcohol during the previous week. Table III shows the overall drinking state of the study group. The proportion of abstainers in the Highlands was roughly double that in the two other areas. 
Highlanders were also less likely than other respondents to report having consumed alcohol in the previous week.

Levels of alcohol consumption-Table IV shows the mean levels of alcohol consumption reported by men and women in the three areas. Significant differences were reported in the mean amounts consumed during the previous week by both sexes in the three areas. Among men, those in Tayside drank the most; whereas among women, those in Kent were the heaviest drinkers. Highlanders drank the least. These differences did not appear to arise from either sampling or response bias (Crawford, and Crawford et al, unpublished observations)

TABLE IV-Mean levels of self reported alcohol consumption (units*) among respondents who had consumed alcohol during previous week

\begin{tabular}{|c|c|c|c|c|}
\hline \multirow{2}{*}{ Respondents } & \multicolumn{3}{|c|}{ Area } & \multirow{2}{*}{ Level of significance $†$} \\
\hline & Highland & Tayside & Kent & \\
\hline $\begin{array}{l}\text { Men } \\
\text { Women }\end{array}$ & $\begin{array}{r}15 \cdot 4 \\
5 \cdot 5\end{array}$ & $\begin{array}{r}19 \cdot 1 \\
6 \cdot 6\end{array}$ & $\begin{array}{r}16 \cdot 9 \\
7 \cdot 2\end{array}$ & $\begin{array}{l}\text { Region: } F=5.7 ; \mathrm{df}=2,1407 ; \mathrm{p}<0.003 \\
\text { Sex: } \mathrm{F}=218.5 ; \mathrm{df}=1,1407 ; \mathrm{p}<0.001\end{array}$ \\
\hline
\end{tabular}

*Each unit equivalent to half pint $(285 \mathrm{ml})$ ordinary beer, lager, etc, or single glas of wine or spirits. Each unit contains approximately $1.0 \mathrm{cl} / 7 \cdot 9 \mathrm{~g}$ absolute alcohol $\dagger 3$ (Area) $\times 2$ (respondent's sex) analysis of variance with scores logged to base 10 .

\section{Conclusions}

These results do not support the view that levels of alcohol consumption in the community mirror officially recorded rates of treated morbidity for alcohol dependence. In this respect this general population survey produced results fully compatible with those of our clinical survey. ${ }^{1}$ Together these studies suggest that the widespread belief that alcohol dependence is vastly more commonplace in the north than in the south of Britain is more of a myth than a reality. Regional differences in other indicators of alcohol misuse remain to be explained. Several policy options exist whereby alcohol misuse may be curbed. These range from controlling the price and availability of alcohol to attempting to make public drinking more relaxed and socially integrated. Some of these are reviewed elsewhere. ${ }^{13}$

This study was funded by the Economic and Social Research Council and the Medical Research Council. Additional support was given by the Scotch Whisky Association and by the Brewers' Society. Fieldwork was efficiently conducted by Survey Research Associates, London. Some of the data will be included in a Glasgow University $\mathrm{PhD}$ thesis.

\section{References}

1 Latcham RW, Kreitman N, Plant MA, Crawford A. Regional variations in British alcohol morbidity rates: a myth uncovered ? I: Clinical surveys. $B$ Med F 1984;289:1341-3.

2 Camberwell Council on Alcoholism. Women and alcohol. London: Tavistock, 1980

3 Plant ML. Women, drinking and pregnancy. London: Tavistock (in press)

Kish L. A procedure for objective respondent selection within the household. fournal of the American Statistical Association 1949;44:380-7

Plant MA, Pirie F. Self-reported alcohol consumption and alcohol-related problems: a study in four Scottish towns. Soc Psychiatry 1979;14:65-73.

Dight S. Scottish drinking habits. London: HMSO, 1976.

7 Plant MA. Drinking careers. London: Tavistock, 1979. second working party on respondent co-operation. Committee. Report of the Recond worch Society 1981;23:3-25.
Researing party on res

9 O'Connor J. The young drinkers. London: Tavistock, 1978.

10 Office of Population Censuses and Surveys. General household survey 1978. London: HMSO, 1980.

ffice of Population Censuses and Surveys. General household survey 1982 London: HMSO, 1984.

12 Crawford A. Response rates in British general population surveys of alcohol consumption: a comparison. Alcohol and Alcoholism 1984;19:141-5

13 Plant MA. Alcohol in Britain: patterns, policies, paradoxes and public policy. In: Single E, Storm T, eds. Public drinking and public policy. Toronto: Addiction Research Foundation (in press).

(Accepted 31 August 1984)

\title{
Reliability of cardiotocography in predicting baby's condition at birth
}

\author{
P CURZEN, J S BEKIR, D G MCLINTOCK, M PATEL
}

\begin{abstract}
A prospective study of 6825 labours was undertaken to determine the relation between the Apgar scores of the babies at one minute and the cardiotocograph tracing in labour. The sensitivity of an abnormal tracing was $35.2 \%$ for babies who needed intermittent positive pressure ventilation and $20.0 \%$ for babies who did not but who had Apgar scores of less than 7. The sensitivity of an abnormal tracing for all babies with an Apgar score of less than 7 was $23.2 \%$. The positive predictive value of an abnormal tracing was $8.7 \%$ for babies who needed intermittent positive pressure ventilation and
\end{abstract}

Obstetric Unit, Charing Cross and Westminster Medical School, Queen Mary's Hospital, London SW15 5PN

P CURZEN, MD, FRCOG, professor

J S BEKIR, FRCS, MRCOG, lecturer

D G MCLINTOCK, MB, MRCOG, lecturer

Department of Computer Medicine, Westminster Hospital M PATEL, operations manager

Correspondence to: Professor P Curzen.
18.7\% for babies who did not but who had an Apgar score of less than 7 . The positive predictive value of an abnormal tracing was $27.4 \%$ for all babies with an Apgar score of less than 7. The specificity of the tracing was $93.4 \%$ for babies with an Apgar score of 7 or over. The relatively high incidence of false positive predictions might be explained on the grounds that abnormalities in the cardiotocograph tracing are a more sensitive indicator of hypoxia than the Apgar score. False negative predictions might have been due to adverse factors other than hypoxia-for example, fetal trauma, compression of the head, infection, and analgesia in labour.

These findings suggest that the current overdependence on fetal monitoring by cardiotocography alone should be examined and that other reliable indicators for non-hypoxic fetal distress should be sought.

\section{Introduction}

Continuous monitoring of the fetal heart rate in labour is now widespread, but the fetal benefits of this have been questioned. ${ }^{1}$ Earlier papers reporting the results of randomised controlled trials showed that continuous monitoring was associated with a 